To Maega | Jurnal Pengabdian Masyarakat

Oktober, Vol.4, No.3, hal, 377-385

$\operatorname{ISSN}(P): 2622-6332 ; \operatorname{ISSN}(E): 2622-6340$

http://www.ojs.unanda.ac.id/index.php/tomaega

\title{
Penanggulangan Stunting Melalui Peningkatan Partisipasi Masyarakat dengan Sosialisasi dan Edukasi Pola Hidup Sehat di Kabupaten Lombok Barat
}

\author{
Syamsia Syamsia ${ }^{1 *}$, Abubakar Idhan ${ }^{2}$, Juliani Ibrahim ${ }^{3}$, Muh. Yunus Ali ${ }^{4}$, Abd \\ Rakhim ${ }^{4}$, Hasanuddin ${ }^{5}$ \\ ${ }^{1}$ Program Studi Agroteknologi, Fakultas Pertanian, Universitas Muhammadiyah Makassar \\ 2 Program Studi Agroteknologi, Fakultas Pertanian, Universitas Muhammadiyah Makassar \\ ${ }^{3}$ Program Studi Kedokteran, Fakultas Kedokteran dan Ilmu Kesehatan, Universitas \\ Muhammadiyah Makassar \\ ${ }^{4}$ Program Studi Teknik Pengairan, Fakultas Fakultas Teknik, Universitas Muhammadiyah \\ Makassar \\ ${ }^{5}$ Program Studi Hukum Ekonomi Syariah, Fakultas Agama Islam, Universitas \\ Muhammadiyah Makassar \\ *Correspondent Email: syamsiatavibe@unismuh.ac.id
}

Article History:

Received: 28-09-2021; Received in Revised: 18-10-2021; Accepted: 26-10-2021

DOI: http://dx.doi.org/10.35914/tomaega.v4i3.894

\begin{abstract}
Abstrak
Stunting merupakan kondisi pertumbuhan anak yang tidak sesuai umurnya karena tidak mendapatkan asupan gizi dalam jumlah tepat dalam waktu yang lama. Kabupaten Lombok Barat merupakan salah satu daerah dengan prevalensi stunting yang tinggi. Tujuan kegiatan pengabdian masyarakat yang melibatkan mahasiswa Kuliah Kerja Nyata (KKN) Muhammadiyah Aisyiah (KKN MAS) di Kabupaten Lombok Barat ini bertujuan untuk:1) meningkatkan keterampilan mahasiswa sebagai sasaran antara yang strategis dalam meningkatkan partispasi masyarakat melalui sosialisasi dan edukasi pola hidup sehat; 2) melibatkan mahasiswa dalam peningkatan partisipasi masyarakat dalam penanggulangan stunting di Kabupaten Lombok Barat; 3) mengembangakan pola pemberdayaan kolaboratif melalui pendampingan dalam transfer ipteks secara luas; 4) meningkatkan partisipasi masyarakat dalam penanggulangan stunting. Metode yang digunakan dalam kegiatan ini adalah sosialisasi dan edukasi pola hidup sehat. Hasil dari kegiatan ini adalah mahasiswa terlibat secara langsung dalam kegiatan sosialisasi dan edukasi pola hidup sehta yang dilakukan secara dor to dor kepada ibu-ibu, dan sosialisasi dan penyuluhan parameter gizi seimbang kepada kader posyandu, serta "sex education" pada siswa. Kegiatan KKN MAS di Lombok Barat terlaksana sesuai dengan yang diharapakan berkat kerjasama peserta KKN MAS, masyarakat, dan pemerintah.
\end{abstract}

Kata Kunci: gizi, pernikahan dini, sex education.

\begin{abstract}
Stunting is a growth condition of children that is not appropriate for their age because they do not get the right amount of nutrition for a long time. West Lombok Regency is one of the areas with a high prevalence of stunting. The purpose of community service activities involving Kuliah Kerja Nyata (KKN) Muhammadiyah Aisyiyah (KKN MAS) in West Lombok Regency aims to: 1) improve student skills as strategic intermediate targets in
\end{abstract}


increasing community participation through socialization and education on healthy lifestyles; 2) involving students in increasing community participation in stunting prevention in West Lombok Regency; 3) developing collaborative empowerment patterns through assistance in broad science and technology transfer; 4) increase community participation in stunting prevention. The method used in this activity is socialization and education on healthy lifestyles. The result of this activity is that students are directly involved in socialization and education activities for healthy lifestyles which are carried out door-to-door to mothers, and socialization and counseling of balanced nutrition parameters to posyandu cadres, as well as "sex education" to students. KKN MAS activities in West Lombok were carried out as expected thanks to the collaboration of KKN MAS participants, the community, and the government

Key Word: nutrition, early marriage, sex education

\section{Pendahuluan}

Stunting adalah permasalahan gizi krosnis yang disebabkan kurangnya asupan gizi dalam rentang waktu yang lama karena asupan makanan yang tidak sesuai dengan kebutuhan gizi (Junaidi, Hakim, \& Elmas, 2020). Stunting (Kerdil) pada anak mencerminkan kondisi kegagalan pertumbuhan pada anak usia di bawah 5 tahun akibat dari kekurangan gizi kronis sehingga anak menjadi pendek untuk usianya. Salah satu penyebab stunting adalah kurangnya akses rumah tangga/keluarga terhadap makanan bergizi. Stunting dapat menghambat pertumbuhan ekonomi dan menyebabkan kemiskinan antar generasi. Indonesia merupakan salah satu negara dengan prevalensi stunting yang cukup tinggi dan Kabupaten Lombok Barat (KLB) merupakan salah satu daerah dengan prevalensi stunting yang tinggi. Data tahun 2020 menunjukkan daerah ini memiliki 16 lokus desa stunting. Menurut (Wantina, Rahayu, \& Yuliana, 2017), persentase balita pendek tertinggi pada tahun 2013 terdapat di Propinsi Nusa Tenggara Timur (51,7\%), Sulawesi Barat (48\%), dan Nusa Tenggara Barat (45,3\%).

Stunting dipengaruhi oleh beberapa faktor seperti infeksi, inisiasi menyusui dini, pemberian ASI ekslusif, berat badan lahir rendah (BBLR) dan pernikahan dini (Windasari, Syam, \& Kamal, 2020). Salah satu penyebab tingginya kasus stunting di Kabupaten Lombok Barat adalah pola konsumsi ibu hamil dan anak dibawah usia 2 tahun yang hanya mengkonsumsi beras, jagung dan umbi-umbian yang memiliki kandungan vitamin, protein dan mineral yang rendah. Terbatasnya pengetahuan masyarakat tentang makanan bergizi dan pentingnya variasi makanan yang bernutrisi serta pernikahan dini di daerah tersebut menjadi penyebab kurangnya asupan gizi terutama pada ibu hamil dan balita. Menurut (Hwalla et al., 2017);(Budiastutik \& Rahfiludin, 2019), penyebab terjadinya stunting adalah penyapihan ASI dini, tinggi badan ayah, konsumsi air minum yang tidak diolah, dan lingkungan kumuh.

Pencegahan stunting dapat dilakukan dengan cara; 1) pemenuhan gizi bagi ibu hamil; 2) pemberian Air Susu Ibu (ASI) ekslusif sampai umur 6 bulan dan pemberian makanan pendamping ASI dalam jumlah cukup dan berkualitas setelah umur 6 bulan; 3) memantau pertumbuhan balita di posyandu; 4) meningkatkan 
akses terhadap air bersih dan fasilitas serta menjaga kebersihan lingkungan (Sutarto, Mayasari, \& Idriyani, 2018)

Kuliah Kerja Nyata Muhammadiyah Aisyiyah (KKN MAS) yang dilaksanakan di Kabupaten Lombok Barat merupakan KKN pertama yang melibatkan seluruh Perguruan Tinggi Muhammadiyah dan Aisyiyah (PTMA) yang merupakan kegiatan pemberdayaan masyarakat yang dilaksanakan oleh mahasiswa. Salah satu masalah yang akan ditangani mahasiswa dalam pelaksanaan KKN MAS ini adalah stunting dengan tema:” Penanggulangan Stanting Melalui Peningkatan Partisipasi Masyarakat dengan Sosialisasi dan Edukasi Pola Hidup Sehat di Lombok Barat".

Desa Banjur, Desa Buwun Sejati, dan Desa Jati merupakan lokasi KKN MAS di Kabupaten Lombok Barat yang menghadapi masalah stunting. Salah satu penyebabnya adalah kurangnya pemahaman orang tua mengenai gizi anak terutama terkait pemberian ASI ekslusif pada anak.

Kegiatan KKN MAS di Kabupaten Lombok Barat bertujuan untuk:1) meningkatkan partisipasi masyarakat dalam penanggulangan stunting di Kabupaten Lombok Barat; 2) meningkatnya keterampilan mahasiswa sebagai sasaran antara yang strategis dalam meningkatkan partisipasi masyarakat melaui sosialisasi dan edukasi pola hidup sehat.; 3) melibatkan mahasiswa dalam peningkatan partisipasi masyarakat dalam penanggulangan stunting di Kabupaten Lombok Barat; 4) Mengembangkan pola pemberdayaan kolaboaratif melalu pendampingan dalam transfer ipteks secara luas.

Sasaran Kegiatan KKN MAS adalah:1) peningkatan partisipasi masyarakat dalam penanggulangan stuting di Kabupaten Lombok Barat; 2) Peningkatan keterampilan mahasiswa dalam melakukan sosialisasi dan edukasi pola hidup sehat; 3) tersedianya sistem pemberdayaan kolaboratif sehingga dapat digunakan dalam mengembangkan kerjasama yang lebih intensif antara perguruan tinggi dengan institusi non formal; 4) membangun kemitraan dan kerjasama yang efektif antara perguruan tinggi dengan kelompok kader posyandu di Kabupaten Lombok Utara (KLU).

Melalui kegiatan KKN MAS ini diharapkan mahasiswa sebagai peserta KKN MAS ini dapat berkontribusi secara langsung dalam meningkatkan partisipasi masyarakat dalam penanggulangan Stunting melalui sosialisasi dan edukasi pola hidup sehat.

\section{Metode}

Metode Pelaksanaan kegiatan yang digunakan dalam kegiatan ini adalah sebagai berikut:

\section{Persiapan Peserta KKN MAS}

Pembukaan pendaftaran dan seleksi peserta KKN MAS melalui web.

Simplemas Unismuh Makassar. Pelepasan peserta KKN MAS dipimpin oleh Rektor Universitas Muhammadiyah Makassar dan dihadiri oleh Ketua BPH 
Unismuh, Ketua LP3M berserta staf, Dekan Fakultas Pertanian, Dekan Fakultas Agama, Dosen Pendamping Lapangan.

3. Pembekalan KKN MAS

Pembekalan peserta KKN MAS dibagi dalam 2 tahap. Tahap 1 dilaksanakan secara daring sebelum pemberangkatan peserta ke Lombok dan Tahap II dilaksanakan secara blended (daring dan luring) setelah semua peserta KKN MAS dari berbagai Perguruan Tinggi Muhammadiyah Aisyiyah tiba di Lombok.

4. Pelaksanaan KKN MAS

Pelaksanaan KKN MAS selama 1 bulan dari tanggal 12 Agustus - 12 September 2021. Peserta KKN MAS dari Universitas Muhammadiyah Makassar yang ditempatkan di Kabupaten Lombok Barat sebanyak 8 orang.

Tahapan pelaksanaan kegiatan KKN MAS setelah peserta tiba di lokasi adalah:

a. Observasi melakukan survei dengan berkunjung secara langsung ke apparat desa, dusun ketua puskesmas, sekolah-sekolah dan warga untuk melakukan wawancara untuk mendapatkan informasi atau data awal tentang kondisi warga terkait stunting

b. Penyusunan program kerja

Berdasarkan hasil observasi peserta KKN MAS Menyusun program kerja untuk mengatasi permasalahan terkait masalah stunting yang dihadapi warga di lokasi KKN

c. Sosialisasi dan Pelaksanaan kegiatan KKN MAS

Kegiatan sosialisasi dilakukan melalui kunjungan ke rumah warga, apparat desa, kader posyandu dan sekolah yang ada di lokasi KKN MAS

d. Evaluasi kegiatan

Evaluasi kegiatan dilakukan pada bagian terakhir dari rangkaian kegiatan KKN MAS dengan tujuan untuk mengetahui apakah kegiatan yang telah diprogramkan berjalan sesuai sasaran dan tujuan dari Program KKN MAS.

\section{Hasil dan Pembahasan}

\subsection{Persiapan Peserta KKN MAS}

Pendaftaran peserta dilakukan secara on line melalui web https://simpelmas.unismuh.ac.id/. Peserta yang mendaftar dan lolos seleksi sebanyak 20 orang yang berasal dari 3 program studi yaitu Prodi Hukum Ekonomi Syariah (16 orang), Prodi Agribisnis (3 orang) dan Prodi Biologi (1 orang).

Pelepasan peserta KKN MAS oleh Rektor Unismuh Makassar dilaksanakan pada tanggal 7 Agustus 2021 di Aula UBC 1t. 1 Gedung Iqra Unismuh Makassar yang dihadiri oleh Ketua BPH, Dekan Fakultas Agama Islam dan Dekan Fakultas Pertanian, Ketua LP3M bersama staf, dosen pendamping lapangan serta peserta KKN MAS. 


\subsection{Pembekalan Peserta KKN MAS}

Pembekalan Tahap I peserta KKN MAS dilakukan secara daring sebelum peserta berangkat ke Lombok. Pemateri pada pembekalan tahap pertama adalah Menteri Pariwisata dan Ekonomi Kreatif, Kepala BKKBN RI dan Panitia Pusat KKN MAS.

Pembicara pada pembekalan Tahap II adalah Kepala BKKBN RI Bapak dr. Hasto Wardoyo, Sp.OG(K), Wakil Gubernur Nusatenggara Barat, Ibu Dr. Ir.Hj. Sitti Rohmi Djalillah, M.Pd. dan Rektor Universitas Muhammadiyah Mataram Bapak Dr.H.Arsyad Abd Gani, M.Pd .

\subsection{Pelaksanaan KKN MAS}

\subsubsection{Observasi}

Pelaksanaan KKN MAS selama 1 bulan dari tanggal 12 Agustus - 12 September 2021. Peserta KKN MAS yang ditempatkan di Desa Bajur Kecamatan Labuapi, Buwun Sejati Kecamatan Narmada, dan Desa Jati Sela Kecamatan Gunung Sari Kabupaten Lombok Barat melaksanakan kegiatan terkait penangan stunting

Kegiatan observasi dilakukan oleh peserta KKN MAS dengan melakukan kunjungan lapang secara langsung, melakukan wawancara dengan apparat desa, dusun, tokoh masyarakat, kepala puskesmas, kader posyandu dan warga serta siswa.

Berdasarkan hasil observasi yang dilakukan di Desa Bajur, Buwun Sejati, Desa Jati Sela dan Desa Kuripan, dapat diidentifikasi permasalahanpermasalahan yang dihadapi warga desa terkait kesehatan diantaranya; 1) kurangnya pemahaman masyarakat mengenai gizi seimbang untuk anak; 2) kurangnya pemahaman masyarakt tentang efek pernikahan dini. Menurut Joko et al.,2019;(Putu, Sri, Putra, \& Purnomo, 2020), penyebab stunting adalah pola asuh anak yang kurang baik, akses layanan kesehatan, air bersih dan makanan bergizi yang kurang.

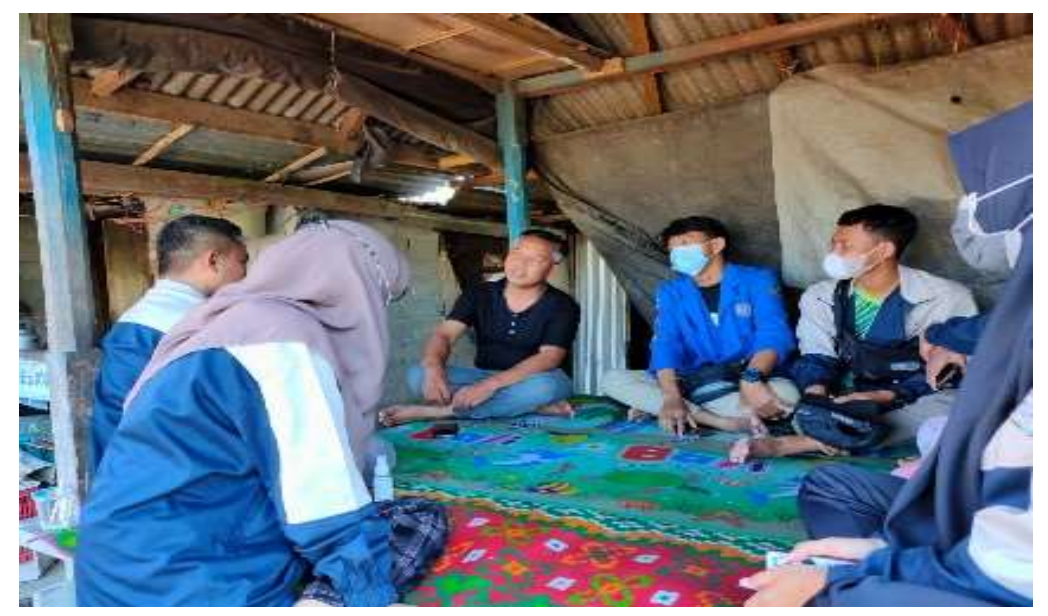

Gambar 1. Observasi dan Silaturahmi 


\subsection{Sosialisasi Stunting}

Sosialisasi penanganan stunting dilakukan melalui kunjugan ke rumah warga dengan tujuan memberikan pemahaman kepada masyarakat terkait faktor-faktor penyebab stunting dan pencegahan pernikahan dini, serta pola hidup sehat. Materi yang disampaikan dalam kegiatan ini adalah pengertian stunting dan cara pencegahannya. Melalui kegiatan ini peserta KKN MAS dapat berdialog secara langsung dan melihat kondisi anak yang menderita stunting. Menurut (Nuryani, 2013), anak yang memiliki postur tubuh yang pendek (kerdi) dapat disebabkan oleh asupan gizi yang buruk atau menderita penyakit infeksi yang berulang.

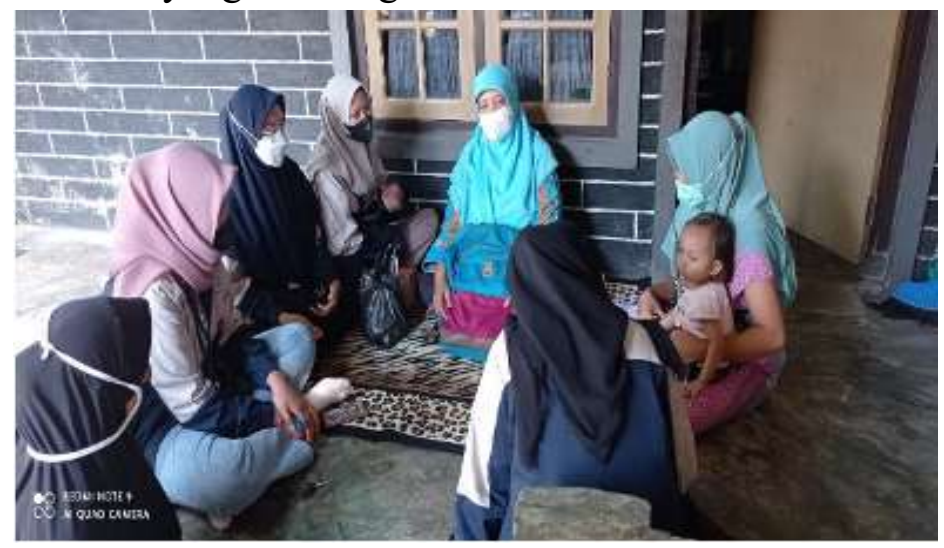

Gambar 2. Penyuluhan Stunting di Desa Bajur

\subsubsection{Sosialisasi Parameter Gizi Seimbang}

Sosialisasi parameter gizi seimbang mencakup pemberian makanan tambahan dengan tujuan memberikan pemahaman kepada orang tua tentang asupan gizi yang perlu diperhatikan pada pemberian penganan atau sarapan untuk anak. Kegiatan ini diharapkan dapat meningkatkan kesadaran dan mengubah perilaku masyarakat untuk mencegah stunting pada periode 1000 HPK (hari Pertama Kelahiran) anak.

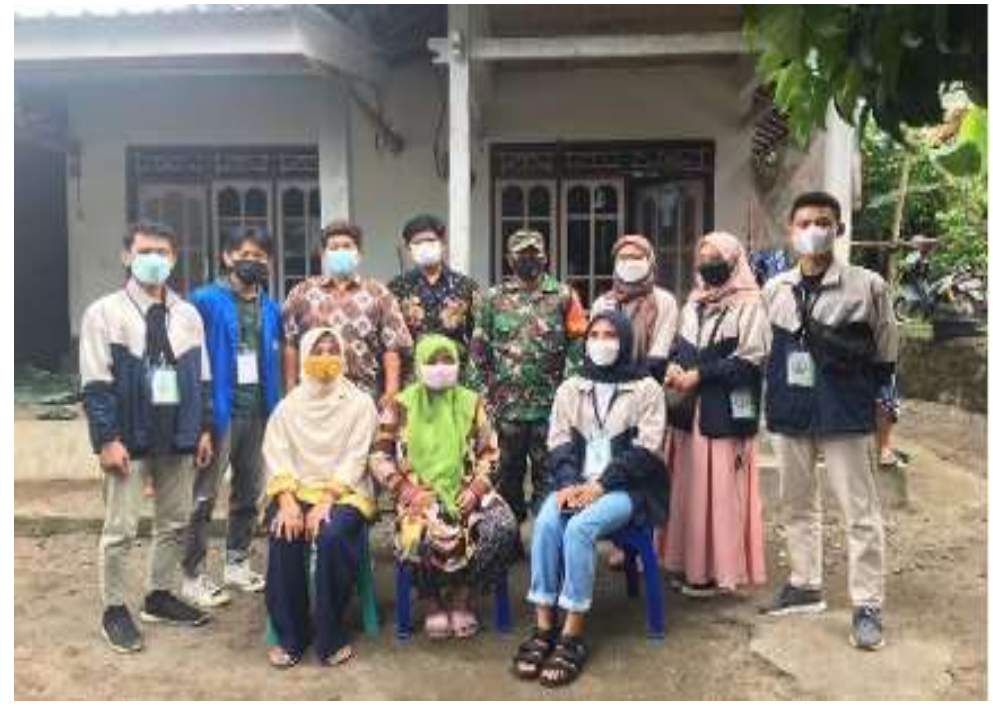

Gambar 3. Sosialisai Parameter gizi Seimbang (Posyandu) 


\subsubsection{Edukasi Pola Hidup Sehat}

Penangan stunting tidak cukup hanya melalui penanganan dari segi kecukupan gizi, tetapi juga perlu dibudayakan hidup sehat melaui perubahan pola hidup sehat (Sriwijayanti \& Devi, 2020).

Peserta KKN MAS melakukan upaya penanganan stunting melalui kegiatan proses pembelajaran di sekolah dasar dan mengajarkan pola hidup sehat kepada siswa. Edukasi pola hidup sehat dilakukan pada 4 sekolah dasar yang ada di lokasi KKN. Menurut (Sriwijayanti \& Devi, 2020), penyuluhan dapat dilakukan untuk edukasi tentang Perilaku Hidup Bersih dan Sehat (PHBS).

Proses evaluasi dilakukan pada bagian akhir pembelajaran untuk mengetahui tingkat pemahaman siswa terhadap materi pola hidup sehat yang telah diajarkan sehingga dapat diterapkan dalam kehidupan sehari-hari.

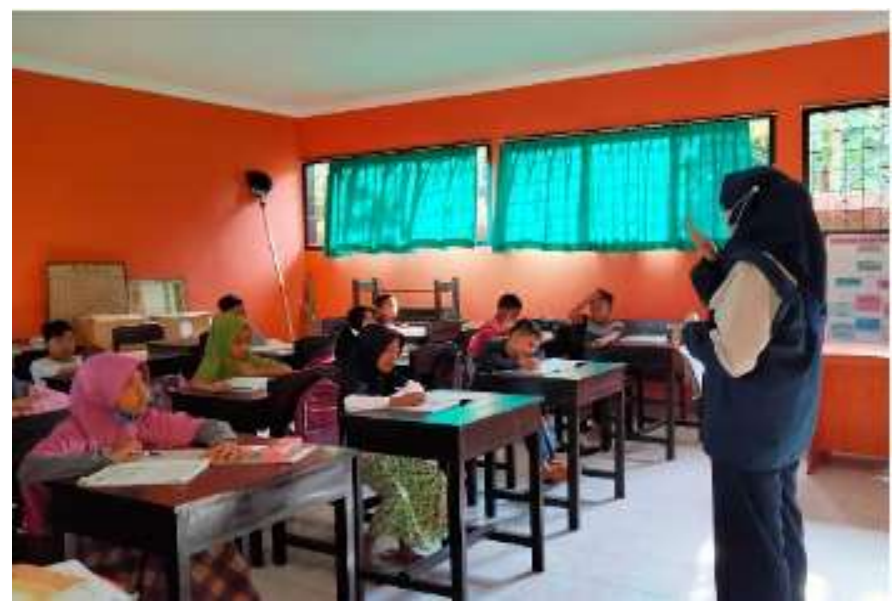

Gambar 4. Edukasi Pola Hidup Sehat di Sekolah

Kegiatan sanitasi protokol Kesehatan Covid-19 di sekolah bertujuan untuk meningkatkan pemahanan dan kesadaran masyarakat tentang pentingnya menjaga kebersiahan diri serta lingkungan dengan rajin mencuci tangan sesuai protokol kesehatan.

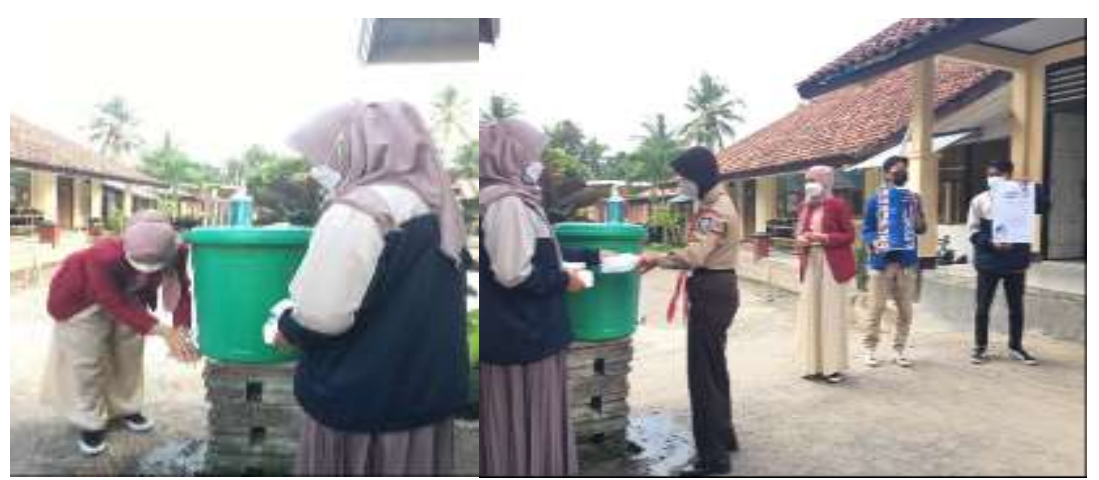

Gambar 5. Sanitasi Protokol Kesehatan Covid-19 


\subsubsection{Sex Education dan Pernikahan Dini}

Kegiatan sex education di sekolah bertujuan untuk meningkatkan kesadaran remaja tentang pergaulan bebas dan dampak dari pernikahan dini. Menurut WHO pernikahan dini adalah pernikahan sebeum usia 18 tahun. Pernikahaan dini dipengaruhi oleh beberapa faktor, diantaranya adalah norma budaya dan soasial yang berlaku di masyarakat, status ekonomi dan tingkat pendidikan (Khusna \& Nuryanto, 2017)

Penyuluhan tentang pernikahan dini dan dampaknya pada generasi muda dilaksanakan di Desa Kuripan. Menurut (Khusna \& Nuryanto, 2017), pernikahan dini dipengerauhi oleh: 1) norma budaya dan sosial yang berlaku di masyarakat, status ekonomi dan tingkat pendidikan. Menurut (Irwansyah, Ismail, \& Hakimi, 2016), kehamilan pada usia yang masih muda yaitu dibawah 20 tahun secara tidak langsung menjadi salah satu faktor penyebab terjadinya stunting.

Salah satu kegiatan yang dilakukan oleh peserta KKN MAS di Desa Kuripan adalah penyuluhan pencegahan pernikahan dini kepada remaja yang ada di Desa Kuripan, melalui kegiatan ini diharapkan remaja mendapatkan pengetahuan tentang dampak dari pernikahan dini terhadap kesehatan reproduksi dan balita.

3.4 Evaluasi

Hasil evaluasi pelaksanaan program KKN MAS selama 30 hari berjalan sesuai rencana. Warga setempat sangat antusias menerima kedatangan para mahasiswa KKN MAS yang berasal dari berbagai Perguruan Tinggi Muhammadiyah Aisyiyah yang ada di Indonesia.

\section{Kesimpulan}

Pelaksanaan kegiatan KKN MAS di Kabupaten Lombok Barat terlaksana sesuai dengan yang diharapkan. Program kerja yang telah disusun untuk penangulangan stunting melalui sosialisasi dan edukasi berjalan sesuai rencana. Peserta KKN melakukan sosialisasi dan edukasi kepada masyarakat terutama ibu rumah tangga, kader posyadu, dan siswa melalui kegiatan sosialisasi dan penyuluhan stunting untuk meningkatkan partisipasi masyarakat dalam penanganan stunting.

\section{Ucapan Terima kasih}

Ucapan terima kasih kepada LP3M Universitas Muhammadiyah Makassar yang telah mendanai kegiatan pengabdian masyarakat ini melalui hibah pengabdian KKN Tematik (KKN T) internal Unismuh Makassar Tahun Anggaran 2021.

\section{Daftar Pustaka}

Budiastutik, I., \& Rahfiludin, M. Z. (2019). Faktor Risiko Stunting pada anak di Negara Berkembang Risk Factors of Child Stunting in Developing Countries. 
Amerta Nutrition, 122-126. https://doi.org/10.2473/amnt.v3i3.2019.122-129

Hwalla, N., Al Dhaheri, A. S., Radwan, H., Alfawaz, H. A., Fouda, M. A., AlDaghri, N. M., ... Blumberg, J. B. (2017). The prevalence of micronutrient deficiencies and inadequacies in the middle east and approaches to interventions. Nutrients, 9(3), 1-28. https://doi.org/10.3390/nu9030229

Irwansyah, I., Ismail, D., \& Hakimi, M. (2016). Kehamilan remaja dan kejadian stunting pada anak usia 6-23 bulan di Lombok Barat. Berita Kedokteran Masyarakat, 32(6), 209. https://doi.org/10.22146/bkm.8628

Junaidi, J., Hakim, L., \& Elmas, M. S. H. (2020). Penerapan Teknologi Hidroponik Tanaman Sawi Sebagai Salah Satu Upaya Pencegahan Stunting di Desa Pikatan Kecamatan Gending Kabupaten Probolinggo. Jurnal Abdi Panca Mara, 1(1), 1-5. https://doi.org/10.51747/abdipancamarga.v1i1.633

Khusna, N. A., \& Nuryanto. (2017). Hubungan Usia Ibu Menikah Dini dengan Status Gizi Batita di Kabupaten Temanggung. Journal of Nutrition College, $6(1)$.

Nuryani. (2013). Potensi Subtitusi Beras Putih Dengan Beras Merah Sebagai Makanan Pokok Untuk Perlindungan Diabetes Melitus. Media Gizi Masyarakat Indonesia, 3(3), 157-168.

Putu, N., Sri, D., Putra, A., \& Purnomo, K. I. (2020). Rumah Sebagai Upaya Pencegahan Stunting Di Desa. 1130-1134.

Sriwijayanti, R. P., \& Devi, N. U. K. (2020). Implementasi Pola Hidup Sehat di Kalangan Anak-Anak Guna Mencegah Stunting di Kelurahan Pakistaji Kecamatan Wonoasih Kota Probolinggo. Jurnal Abdi Panca Mara, 1(1), 912. https://doi.org/10.51747/abdipancamarga.v1i1.637

Sutarto, Mayasari, D., \& Idriyani, R. (2018). Stunting, Faktor Resiko dan Pencegahannya. Jurnal Agromedicine, 5(1), 540-545. https://doi.org/10.1201/9781439810590-c34

Wantina, M., Rahayu, L. S., \& Yuliana, I. (2017). Keragaman konsumsi pangan sebagai faktor risiko stunting pada balita usia 6-24 bulan. Journal UHAMKA, 2(2), 89-96.

Windasari, D. P., Syam, I., \& Kamal, L. S. (2020). Faktor Hubungan dengan Kejadian Stunting di Puskesmas Tamalate Kota Makassar (Factors related to the incidence of stunting at the Tamalate health center in Makassar city ). Aceh Nutrition Jurnal, 2020(5), 27-34. Retrieved from http://dx.doi.org/10.30867/action.v5i1.193 